\title{
Institutional Ownership Mispricing and Corporate Investment
}

\author{
Weili Wu1, Lian Wang2 \\ School of Management, Jinan University, Guangzhou, China \\ Guangzhou Branch, Industrial Bank Co., Guangzhou, China \\ Email: jnunighterwoo@163.com,itscleanlake@yeah.net
}

Received 18 March 2016; accepted 23 April 2016; published 26 April 2016

Copyright (C) 2016 by authors and Scientific Research Publishing Inc.

This work is licensed under the Creative Commons Attribution International License (CC BY). http://creativecommons.org/licenses/by/4.0/

\section{(c) (i) Open Access}

\begin{abstract}
Behavioral finance suggests that mispricing is positively related to corporate investment, and overvalued (undervalued) firms tend to over (under)-invest, which leads to the inefficiency of investment, and we studies whether institutional investors enlarge or reduce the impact of mispricing on investment, by decomposing the market-to-book ratio into mispricing and growth components. The result shows that investor sentiment directly affects the corporate investment. This investment-mispricing link is more pronounced in firms with higher institutional investor ownership. Our evidence suggests that institutional investors such as insurance firms and trust will amplify this link. This study can provide real economy with evidence, and evaluate the role institution play and economy impact, which have certain reference significance for the securities market regulation and policy making departments.
\end{abstract}

\section{Keywords}

Mispricing, Institutional Investor, Corporate Investment, Pressure-Sensitive

\section{Introduction}

As investors heterogeneous beliefs, the existence of the risk and cost and arbitrage, lead to stock prices deviated from its fundamental value. According to behavioral finance, mispricing is usually caused by investors' irrational expectations of stock value, and this is referred as investor sentiment. Liu proves that investor sentiment/mispricing affects the corporate stock price and in return, affects the corporate operation, especially the corporate investment decisions [1]. Farhi and Panageas indicate that mispricing distorts the normal investment decisionmaking of the firms, leading to the investment efficiency [2]. Polk and Sapienza suggest that investor sentiment, or mispricing affects the corporate investment decision making, and the longer the duration, the more serious 
investment inefficiency is [3].

On the other hand, in order to adapt to the international situation development and active capital market, China Securities Regulatory Commission (CSRC) put forward in 2000 "extraordinary development of institutional investors", as the important measure to improve the investor structure of the capital market. By 2011, the stock market value of tradable shares held by the institutional investors reached to 70\%, with the high-speed development of institutional investors, concern about the institutional investors has arisen. Institutional investors can improve the pricing efficiency of stock, make it back to its fundamental value, and reduce the investor sentiment which can improve corporate investment efficiency. Institutional investors regarded as sophisticated investors, can better evaluation towards the firms' relevant information, improving stock pricing efficiency which makes stock price reflect the fundamental value. Prior researches indicate that institutional investor can ease the degree of accrual anomaly. However, there are still studies suggesting that the participation of institutional investors can't improve the pricing efficiency.

In reality, the period of managers in institutions is shorter than the normal investment cycle, and shorter than the time price fully reflects private information of managers, and these rise managers' incentives pay more attention to short-term interests. Moreover, managers who are desperate for short-term interests are more likely to be involved in conspiracy with others. What's more, institutional investors are momentum traders who tend to pursuit of historical price movements. Herd effect between the mutual funds deepens the price deviation degree. It has taken only about 30 years since stock market in China started to develop, and for the lack of legal norms, myopia of investor is very serious, which also makes institutional investors to chase for short-term gains and ignores whether stock price is under/overvalued or fundamentally valued. Prior paper indicates that funds' holdings actually lower the market pricing efficiency regardless in the bearmarket or the bull market and the "'leapfrog development' of the institutional investors fails to lead to a more stable and rational market. The policy of institutional investors" "extraordinary development" does not make the market more rational. Thus this paper studies whether institutional investors improve the pricing efficiency.

Institutional investors as the important part of our capital market are hoped to improve the pricing efficiency of stock and investment efficiency. But there are a variety of reasons that may lead to adverse outcomes. This paper studies whether institutional investors improve corporate investment efficiency by inducing investor sentiment. Prior studies about institutional investors ignore the types of institutional investors. This paper controls the type of institution, and studies different impacts of institutional investors on the corporate investment.

\section{Literature Review and Hypotheses Development}

Traditional finance theory suggests that stock price reflects the marginal output of capital-the investment opportunities. The link between stock price and investment is positive [4]. Keynes ndicates that price bubble of stock involves irrational factors of investors, and these investor irrational factors change the cost of capital and the way on which corporate finance. Follow-up researches suggest that investor irrational factors affect the corporate investment through the equity financing, which concluded as "equity financing channel". Stein found that in the situation of "irrational investors and rational managers" investor sentiment affects the stock price to deviate from fundamental value and rational enterprise managers can choose market timing to issue shares or buy back shares by inducing benchmark model research [5]. Based on Stein's model, Barker, Stein and Wurgler using the $\mathrm{KZ}$ index suggests that firms with financing constraints are more sensitive to mispricing and mispricing leads to investment inefficiency [3].

Equity financing channel theory suggests that investor sentiment affect the corporate investment through the issuance of stock or stock repurchase. If the enterprise has enough internal funds or stronger ability to borrow, is corporate investment irrelevant to stock price, or mispricing caused by investor sentiment? Polk \& Sapienzause discretionary accruals as our proxy for mispricing [3]. We and a positive relation between abnormal investment and discretionary accruals; that abnormal investment is more sensitive to discretionary accruals for firms with higher R\&D intensity (opaque firms) or share turnover (firms with shorter shareholder horizons); that firms with high abnormal investment subsequently have low stock returns; and that the larger the relative price premium, the stronger the abnormal return predictability. Their study shows that patterns in abnormal returns are stronger for firms with higher R\&D intensity or share turnover.

Hypothesis 1: Mispricing and the corporate investment are positively related.

Corporate governance is an important measure to reduce agency cost, and effectively reduce the investment inefficiency. Institutional investors ownership regarded as an important part of corporate governance, are 
thought to directly participate in corporate governance Shleifer and Vishnyargue that institutional investors have the incentive to collect corporate information and monitor managementwhich improves corporate performance [6]. Dobrzynski and Monks and Minowargue that sophisticated institutions with large shareholdings tend to monitor management and make sure that firm's strategy serves firm's long-term value [7]. Chen et al. argue that institutional investors have better knowledge of the firm and larger influence on management and, thus, are more likely to engage in monitoring efforts than other institutions [8]. Chung et al. document that institutional ownership reduces corporate earnings management. Consistent with this monitoring view of institutional investors, empirical studies provide evidence that corporate benefit from institutional investor in a variety of ways such as R\&D investment, executive compensation, management (earnings forecast) disclosures, CEO turnover and anti-takeover amendments [9]. These studies are in consistent with evidence that institutional investor monitoring effect enhance corporate governance and corporate value [10]-[13].

Prior research also provides empirical evidence of this "short-termism" view. Coffee suggests that if monitoring is costly or time-consuming, institutional investors prefer to activities that are in favor of firm's long-term value, rather than corrective action [14]. Studies document that portfolio of institutional investors are more diversified than other shareholders, thus monitoring each firm could be costly. The latter are likely indifferent regarding the governance of individual corporations. Many studies claim that institutional investors place more or excessive emphasis on firm's short-term value, causing management overly concerned on stock price or shortterm value. Bushee documents that firm with larger institutional ownership are more likely to engage in momentum trading, and cut long-term R\&D projects to meet earning targets [15]. Bushee provides evidence that firms dominated by large institutional ownership are more likely to overweight the near-term investment and underweight long-term projects, raising the concerns that institutional shareholders force managers to focus more on the short-term value [16]. In addition institution owner institutional owners are seen to have even shorter time horizons than individual U.S. investors because they are under tremendous pressure to show results to their constituents on a quarterly basis [17]. Overall, there are other evidences suggesting that institutions are shorttermism.

Overall, the literature provides two essentially opposing views of institutional investors which we call monitoring and short-termism.

Hypothesis 2a: Institutional ownership enlarges the investment-mispricing relationship.

Hypothesis 2b: Institutional ownership reduces the investment-mispricing relationship.

For the differences among institutions in fund source, character, period and so on, different institutions may have opposing impact on the mispricing-investment relationship. Thus we examine differences among various types of institutions based on different influence on corporate action. All institutional investor have investment relationship with the firm, but some of them may have business relationship with the firm and economic activity of firm affect the institution' interest, which result in conflict between institutions and firm. Brickley et al. have argued that institutions' ability to influence firm may be limited by the extent to which institution depend on the firm. Some institutions that have business relationship with the firm they invest are more likely to maintain amicable business relationship. As a result, these institutions may be hesitant to involve in monitoring the firm [12]. Brickley et al. term these institutions as pressure-sensitive institution that may have little to do with corporate investment including insurance, trust and general firms [12].

On the other hand, the institutions that have no business relationship with the firm are regarded as pressureresistant institution. Without the business relationship, these institutions have no interest conflicts and are willing to monitor the firm. We define fund, social security fund and QFII as pressure-resistant, and these institution place more emphasis on firm's long-term value. In order to enhance firm's long-term value, they also monitor firm's activity including investment.

Hypothesis 3: Pressure-sensitive institutional ownership is more likely to enlarge mispricing-investment relationship.

Hypothesis 4: Pressure-resistant institutional ownership has no influence on mispricing-investment relationship.

\subsection{Sample, Variables, and Descriptive Statistics}

\section{Sample}

We obtain annual corporate financial statement data from the CSMAR over the period 2009-2014. We exclude finance and insurance firms because the demarcation between operating and financing activities is not clear for these firms. 


\subsection{Measurement of Major Variables}

\section{Dependent variable}

Following Chen et al. and Firth et al., we define corporate investment (INVEST) as the change (from the beginning of financial year to the end of financial year) in net fixed assets plus depreciation, scaled by beginningyear values.

\subsection{Independent Variable}

We measure institutional ownership as the fraction of a firm's shares held by institutional investors and total leverage as a firm's total debt divided by its total assets.

How to measure this mispricing is always a difficult problem. Most research using Tobin'Q or similar variables as a proxy variable to measure mispricing. However, these variables fail to distinguish whether mispricing or investment opportunity, and both of two factors have similar impacts on corporate investment. To solve this issue, this paper divide market-book ratio into two parts: mispricing and growth, by using the measurement of Rhodes-Kropf, Robinson and Viswana than [18].

According to RKRV model, mispricing at the firm level is the difference between the market value of firm $i$ at time $t$ and the fundamental value of firm $i$ at time $t, m_{i, t}-v\left(\theta_{i t} ; \beta_{j}\right)$. Just as model (1), we regress $m_{i, t}$ with firm-specific variables including asset, leverage, net income and we define residual as mispricing.

$$
\begin{gathered}
m_{i, t}=\beta_{0 j t}+\beta_{1 j t} b_{i t}+\beta_{2 j t} n i_{i t}+\beta_{3 j t} I_{i t} n i_{i t}+\beta_{4 j t} \mathrm{LEV}_{i t}+\varepsilon_{i t} \\
v\left(\theta_{i t} ; \beta_{j}\right)=\bar{v}_{i t}=\bar{\beta}_{0 j t}+\bar{\beta}_{1 j t} b_{i t}+\bar{\beta}_{2 j t} n i_{i t}+\bar{\beta}_{3 j t} I_{i t} n i_{i t}+\bar{\beta}_{4 j t} \mathrm{LEV}_{i t}
\end{gathered}
$$

We also other firm-specific variables as control variables. Growth represents corporate growth, using operation revenue growth. SIZE is natural logarithm of total assets. LEV is the leverage of corporate. ARETURN is the abnormal return of the stock. OCF is the net operating cash flow, scaled by total asset. CF is the cash holding, scaled by total asset. ROE is the roe (Rate of Return on Common Stockholders' Equity) of the firm. FISRTHOLD indicates the ratio of the largest shareholder. SHRCR indicates the ratio of the second large shareholder. PAY is natural logarithm of salary of top 3 executives. ACCOV is the other receivables, scaled by total asset. SOE is the property right of firms.

\subsection{Descriptive Statistics}

Table 1 represents descriptive statistics of major variables. We divide firm-specific into overvalued group and undervalued group by measurement of RRSV. We can see there are 3981 firm-specific in undervalued group and 6796 firm-specific in overvalued group, consistent with the prior research, and the result represents that the stock market in China is overvalued. Furthermore, the mean of leverage is higher and the mean of cash holdings is lower in overvalued group. Overvalued firm-specifics have better ROE and GROWTH, with greater perspective. Younger firms tend to be undervalued.

\section{Empirical Results}

\subsection{Primary Specification}

Based on prior studies, we estimate the following regression equation to investigate the relation between institutional ownership and investment-mispricing sensitivity:

$$
\begin{aligned}
I N V_{i, t}= & \alpha+\beta_{1} \mathrm{Mis}_{i, t-1}+\beta_{2} \mathrm{INS}_{i, t}+\beta_{3} \mathrm{Mis} \times \mathrm{INS}_{i, t}+\beta_{4} \mathrm{SIZE}_{i, t}+\beta_{5} \mathrm{LEV}_{i, t} \\
& +\beta_{6} \mathrm{GROWTH}_{i, t}+\beta_{7} \operatorname{Areurn}_{i, t}+\beta_{8} \mathrm{OCF}_{i, t}+\beta_{9} \mathrm{ROE}_{i, t} \\
& +\beta_{10} \text { Firsthold }_{i, t}+\beta_{10} \mathrm{INV}_{i, t-1}+(\text { yeardummy })+(\text { inddummy })
\end{aligned}
$$

where $\mathrm{INV}_{i, t}$ is corporate investment; $\mathrm{Mis}_{i, t-1}$ is the mispricing; $\mathrm{INS}_{i, t}$ is the institutional ownership, and Mis $\mathrm{Mit}_{i, t}$ 1 $^{*}$ $\mathrm{INS}_{i, t}$ is the interaction of mispricing and institutional ownership. Growth represents corporate growth, using operation revenue growth. SIZE is natural logarithm of total assets. LEV is the leverage of corporate. ARETURN is 
Table 1. Descriptive statistics.

\begin{tabular}{|c|c|c|c|c|c|c|}
\hline \multicolumn{7}{|c|}{ A: undervalued (Mis $<0$ ) } \\
\hline Variable & Observation & Mean & Std & Min & Med & Max \\
\hline INV & 3981 & 0.0800 & 0.130 & -0.250 & 0.0500 & 0.860 \\
\hline Mis & 3981 & -0.430 & 1.370 & -69.95 & -0.240 & 0 \\
\hline Size & 3981 & 21.87 & 1.520 & 19.11 & 21.48 & 25.63 \\
\hline LEV & 3981 & 0.330 & 0.220 & 0.0500 & 0.280 & 1.120 \\
\hline $\mathrm{CF}$ & 3979 & 0.100 & 0.210 & -1.100 & 0.0900 & 0.760 \\
\hline CASH & 3875 & 0.280 & 0.210 & 0.0100 & 0.240 & 0.930 \\
\hline ACCVO & 3981 & 0.0100 & 0.0200 & 0 & 0.0100 & 0.190 \\
\hline ROE & 3981 & 0.0600 & 0.100 & -0.660 & 0.0700 & 0.460 \\
\hline Growth & 3976 & 0.190 & 0.440 & -0.610 & 0.130 & 3.570 \\
\hline lnage & 3981 & 1.850 & 0.800 & 0.690 & 1.950 & 3.180 \\
\hline Firsthold & 3981 & 37.99 & 15.99 & 8.940 & 36.72 & 75.25 \\
\hline \multicolumn{7}{|c|}{ B: overvalued (Mis $>0$ ) } \\
\hline Variable & Observation & Mean & Std & Min & Med & Max \\
\hline INV & 6796 & 0.0700 & 0.140 & -0.250 & 0.0400 & 0.860 \\
\hline Mis & 6749 & 0.240 & 0.190 & 0 & 0.210 & 2.090 \\
\hline Size & 8039 & 21.75 & 1.110 & 19.11 & 21.70 & 25.63 \\
\hline LEV & 8039 & 0.550 & 0.180 & 0.0500 & 0.550 & 1.120 \\
\hline $\mathrm{CF}$ & 8036 & 0.0600 & 0.230 & -1.100 & 0.0600 & 0.760 \\
\hline CASH & 6679 & 0.200 & 0.160 & 0.0100 & 0.160 & 0.930 \\
\hline ACCVO & 8039 & 0.0200 & 0.0300 & 0 & 0.0100 & 0.190 \\
\hline ROE & 8039 & 0.0700 & 0.150 & -0.660 & 0.0800 & 0.460 \\
\hline Growth & 8030 & 0.230 & 0.550 & -0.610 & 0.130 & 3.570 \\
\hline lnage & 8039 & 2.240 & 0.630 & 0.690 & 2.400 & 3.180 \\
\hline
\end{tabular}

the abnormal return of the stock. OCF is the net operating cash flow, scaled by total asset. CF is the cash holding, scaled by total asset. ROE is the roe (Rate of Return on Common Stockholders' Equity) of the firm. FISRTHOLD indicates the ratio of the largest shareholder. SHRCR indicates the ratio of the second large shareholder. PAY is natural logarithm of salary of top 3 executives. ACCOV is the other receivables, scaled by total asset. SOE is the property right of firms.

\subsection{Regression Results}

Table 2 represents the result of OLS estimates. We examine the impacts of mispricing on investment. In column (1 - 3), we find that coefficient of mispricing is positive and statically significant at $1 \%$ level.

Model 2 examines the effect of institutional ownership on investment-mispricing link. To testify hypothesis 2 we are primarily interested in the coefficient of the interaction with institutional ownership (INS*MIS), and we find that the coefficient is positive and statically significant at $1 \%$ level. It implies that institutional investor is short-termism rather than monitor, together with that the investment-mispricing link is positive. The result provides evidence that institutional ownership amplifies the relationship between investment and mispricing, in consistent with Hypothesis 2b. 
Table 2. Institutional ownership, mispricing and investment.

\begin{tabular}{|c|c|c|c|}
\hline & MODEL1 & MODEL 2 & endogenous \\
\hline & & & 2GSLS \\
\hline \multirow[t]{2}{*}{ INV_LAG } & $0.052^{* * * *}$ & $0.048^{* * *}$ & $0.042^{* * *}$ \\
\hline & $(0.01)$ & $(0.01)$ & $(0.01)$ \\
\hline \multirow[t]{2}{*}{ Sent } & $0.011^{*}$ & $0.070^{* * *}$ & $0.765^{* * *}$ \\
\hline & $(0.01)$ & $(0.01)$ & $(0.08)$ \\
\hline \multirow[t]{2}{*}{ Inshold } & $-0.000^{* *}$ & $-0.000^{* *}$ & $-0.011^{* * *}$ \\
\hline & $(0.00)$ & $(0.00)$ & $(0.00)$ \\
\hline \multirow[t]{2}{*}{ INS*SENT } & & $0.003^{* * *}$ & $0.026^{* * * *}$ \\
\hline & & $(0.00)$ & $(0.00)$ \\
\hline \multirow[t]{2}{*}{ Size } & $0.024^{* * * *}$ & $0.027^{* * *}$ & $0.039^{* * * *}$ \\
\hline & $(0.00)$ & $(0.00)$ & $(0.00)$ \\
\hline \multirow[t]{2}{*}{ LEV } & -0.00600 & $-0.025^{* * *}$ & 0.0110 \\
\hline & $(0.01)$ & $(0.01)$ & $(0.01)$ \\
\hline \multirow[t]{2}{*}{$\mathrm{CFO}$} & $0.155^{* * * *}$ & $0.130^{* * *}$ & $0.171^{* * *}$ \\
\hline & $(0.04)$ & $(0.03)$ & $(0.03)$ \\
\hline \multirow[t]{2}{*}{ CASH } & $0.051^{* *}$ & $0.040^{* *}$ & -0.0270 \\
\hline & $(0.02)$ & $(0.02)$ & $(0.02)$ \\
\hline \multirow[t]{2}{*}{ GROWTH } & 0 & 0 & 0 \\
\hline & $(0.00)$ & $(0.00)$ & $(0.00)$ \\
\hline \multirow[t]{2}{*}{ DGROWTH } & $-0.036^{* * *}$ & $-0.032^{* * * *}$ & $-0.024^{* * *}$ \\
\hline & $(0.01)$ & $(0.01)$ & $(0.01)$ \\
\hline \multirow[t]{2}{*}{ MFREE } & $0.150^{* * *}$ & $0.135^{* * *}$ & $0.148^{* * * *}$ \\
\hline & $(0.01)$ & $(0.01)$ & $(0.01)$ \\
\hline \multirow[t]{2}{*}{ ROE } & $-0.016^{* * *}$ & $-0.017^{* * * *}$ & $-0.015^{* * *}$ \\
\hline & $(0.00)$ & $(0.00)$ & $(0.00)$ \\
\hline \multirow[t]{2}{*}{ FIRSTHOLD } & 0 & 0 & $-0.001^{* *}$ \\
\hline & $(0.00)$ & $(0.00)$ & $(0.00)$ \\
\hline \multirow[t]{2}{*}{ ARETURN } & $0.018^{* * *}$ & $0.019^{* * * *}$ & 0.0110 \\
\hline & $(0.01)$ & $(0.01)$ & $(0.01)$ \\
\hline \multirow[t]{2}{*}{ SHRCR2 } & $-0.008^{*}$ & $-0.010^{* *}$ & 0 \\
\hline & $(0.00)$ & $(0.00)$ & $(0.00)$ \\
\hline \multirow[t]{2}{*}{ LIANG } & $0.012^{*}$ & 0.0100 & 0.00800 \\
\hline & $(0.01)$ & $(0.01)$ & $(0.01)$ \\
\hline \multirow[t]{2}{*}{ PAY } & $-0.015^{* *}$ & $-0.018^{* * *}$ & $-0.010^{* *}$ \\
\hline & $(0.01)$ & $(0.01)$ & $(0.00)$ \\
\hline \multirow[t]{2}{*}{ LNAGE } & $0.024^{* * *}$ & $0.027^{* * * *}$ & $-0.014^{* * *}$ \\
\hline & $(0.00)$ & $(0.00)$ & $(0.00)$ \\
\hline \multirow[t]{2}{*}{ SOE } & -0.00600 & $-0.025^{* * *}$ & -0.00500 \\
\hline & $(0.01)$ & $(0.01)$ & $(0.01)$ \\
\hline \multirow[t]{2}{*}{ cons } & $-0.320^{* * *}$ & $-0.332^{* * *}$ & $-0.263^{* * *}$ \\
\hline & $(0.07)$ & $(0.07)$ & $(0.07)$ \\
\hline YEAR & \multicolumn{2}{|r|}{ Control } & \\
\hline IND & \multicolumn{2}{|r|}{ Control } & \\
\hline $\mathrm{N}$ & 5613 & 5613 & 5613 \\
\hline $\mathrm{R}^{2}$ & 0.170 & 0.203 & 0.198 \\
\hline Adjusted-R ${ }^{2}$ & 0.165 & 0.197 & 0.193 \\
\hline F & 32.73 & 39.36 & 36.23 \\
\hline
\end{tabular}


In order to eliminate endogenous problem, we use natural logarithm of total number of shareholders as instrumental variable and employ 2GSLS method. By doing this we find that coefficient of interaction remains positive and significant at $1 \%$ level, in consistent with Hypothesis $2 \mathrm{~b}$.

Furthermore we examine the different impacts of institutions on investment-mispricing link. We divide institutions into two groups: pressure-sensitive and pressure-resistant. Pressure-sensitive institutional investors are referred to be involved in business relationship with the firm they invest, and they are more likely to be indifferent to firm's activity. On the other hand, pressure-resistant institutions tend to monitor the economic activity of firms and pressure-resistant institutions will eliminate investment inefficiency. Table 3 presents the result of Hypothesis 3. Model 3 examines the effect of different variety of institutional ownership on investment-mispricing link. To testify Hypothesis 3 we are primarily interested in the coefficient of the interaction with different

Table 3. Institutional ownership types, mispricing and investment.

\begin{tabular}{|c|c|c|}
\hline & \multicolumn{2}{|c|}{ Model 3} \\
\hline & Pressure-resistant & Pressure-sensitive \\
\hline \multirow[t]{2}{*}{ INV_LAG } & $0.047^{* * *}$ & $0.045^{* * * *}$ \\
\hline & $(0.01)$ & $(0.01)$ \\
\hline \multirow[t]{2}{*}{ Sent } & $0.011^{*}$ & 0.00900 \\
\hline & $(0.01)$ & $(0.01)$ \\
\hline \multirow[t]{2}{*}{ INS01 } & 0 & \\
\hline & $(0.00)$ & \\
\hline \multirow[t]{2}{*}{ INS01*SENT } & 0.00100 & \\
\hline & $(0.00)$ & \\
\hline \multirow[t]{2}{*}{ INS02 } & & $0.003^{* *}$ \\
\hline & & $(0.00)$ \\
\hline \multirow[t]{2}{*}{ INS02*SENT } & & $0.008^{* * *}$ \\
\hline & & $(0.00)$ \\
\hline \multirow[t]{2}{*}{ Size } & $0.024^{* * * *}$ & $0.024^{* * * *}$ \\
\hline & $(0.00)$ & $(0.00)$ \\
\hline \multirow[t]{2}{*}{ LEV } & -0.00100 & -0.00200 \\
\hline & $(0.01)$ & $(0.01)$ \\
\hline \multirow[t]{2}{*}{$\mathrm{CFO}$} & $0.155^{* * *}$ & $0.159^{* * *}$ \\
\hline & $(0.04)$ & $(0.03)$ \\
\hline \multirow[t]{2}{*}{ CASH } & 0.0140 & 0.0130 \\
\hline & $(0.02)$ & $(0.02)$ \\
\hline \multirow[t]{2}{*}{ GROWTH } & 0 & 0 \\
\hline & $(0.00)$ & $(0.00)$ \\
\hline \multirow[t]{2}{*}{ DGROWTH } & $-0.030^{* * *}$ & $-0.030^{* * *}$ \\
\hline & $(0.01)$ & $(0.01)$ \\
\hline \multirow[t]{2}{*}{ MFREE } & $0.151^{* * *}$ & $0.152^{* * *}$ \\
\hline & $(0.01)$ & $(0.01)$ \\
\hline \multirow[t]{2}{*}{ ROE } & $-0.016^{* * *}$ & $-0.016^{* * *}$ \\
\hline & $(0.00)$ & $(0.00)$ \\
\hline \multirow[t]{2}{*}{ FIRSTHOLD } & $-0.001^{* *}$ & $-0.001^{* *}$ \\
\hline & $(0.00)$ & $(0.00)$ \\
\hline
\end{tabular}




\begin{tabular}{|c|c|c|}
\hline \multicolumn{3}{|l|}{ Continued } \\
\hline \multirow[t]{2}{*}{ ARETURN } & $0.016^{* *}$ & $0.016^{* *}$ \\
\hline & $(0.01)$ & $(0.01)$ \\
\hline \multirow[t]{2}{*}{ SHRCR2 } & $0.001^{* * *}$ & $0.001^{* * *}$ \\
\hline & $(0.00)$ & $(0.00)$ \\
\hline \multirow[t]{2}{*}{ LIANG } & 0.00900 & 0.0100 \\
\hline & $(0.01)$ & $(0.01)$ \\
\hline \multirow[t]{2}{*}{ PAY } & $-0.011^{* *}$ & $-0.011^{* *}$ \\
\hline & $(0.00)$ & $(0.00)$ \\
\hline \multirow[t]{2}{*}{ LNAGE } & $-0.023^{* * *}$ & $-0.023^{* * *}$ \\
\hline & $(0.00)$ & $(0.00)$ \\
\hline \multirow[t]{2}{*}{ SOE } & -0.00500 & -0.00500 \\
\hline & $(0.01)$ & $(0.01)$ \\
\hline \multirow[t]{2}{*}{ cons } & $-0.289^{* * *}$ & $-0.289^{* * *}$ \\
\hline & $(0.07)$ & $(0.07)$ \\
\hline YEAR & \multicolumn{2}{|c|}{ Control } \\
\hline IND & \multicolumn{2}{|c|}{ Control } \\
\hline $\mathrm{N}$ & 5613 & 5613 \\
\hline $\mathrm{R}^{2}$ & 0.177 & 0.180 \\
\hline Adjusted-R ${ }^{2}$ & 0.171 & 0.174 \\
\hline F & 31.57 & 32.13 \\
\hline
\end{tabular}

institutional ownership (INS01*MIS or INS02*MIS). We find that the coefficient of interaction of pressure-sensitive institutional ownership and mispricing is positive and statically significant at $1 \%$ level. It implies that pressure-sensitive institutional investors are more likely to be short-termism rather than monitor, together with that the investment-mispricing link is positive. The result provides evidence that with effective monitoring, pressure-resistant institutional ownership amplifies the relationship between investment and mispricing. We also find that coefficient of interaction of pressure-resistant institutions ownership is not significant. These results are in consistent with Hypothesis 3.

\section{Conclusion}

We present two opposing effects of institutional ownership on corporate governance: monitoring and shorttermism. In this view, we try to find out whether institutional ownership affects corporate investment. Behavioral finance suggests that mispricing is positively related to corporate investment, and overvalued (undervalued) firms tend to over (under)-invest. Thus mispricing results in investment inefficiency. As the large there are two competing views about institutional ownership, and that is what we want to distinguish. Our study providence is that institutional investor as a whole amplify the investment-mispricing link meaning that institutional investor tends to be short-termism and leads to investment inefficiency. Furthermore we find that different institutional ownerships have different impact on investment-mispricing relationship, and that pressure-sensitive institutional investors are more likely amplifying investment-mispricing relationship while pressure-resistant institutional investor has nothing to do with investment-mispricing relationship. Thus, our results cast strong doubt on effect of different institutional investor and provide evident to regulatory departments.

\section{References}

[1] Liu, Z.Y. and Hua, G.R. (2009) Investor Sentiment and Corporate Investment Efficiency: An Empirical Study on the Moderating Effects of Shareholding Ratio and Rights Separation. Foreign Economics \& Management, 6, 45-51.

[2] Farhi, E. and Panageas, S. (2004) The Real Effects of Stock Market Mispricing at the Aggregate. Theory and Empiri- 
cal Evidence. http://papers.ssrn.com/sol3/papers.cfm?abstract_id=720462

[3] Polk, C. and Sapienza, P. (2009) The Stock Market and Corporate Investment: A Test of Catering Theory. Review of Financial Studies, 22, 187-217. http://dx.doi.org/10.1093/rfs/hhn030

[4] Baker, M., Stein, J.C. and Wurgler, J. (2002) When Does the Market Matter? Stock Prices and the Investment of Equity-Dependent Firms. National Bureau of Economic Research. http://dx.doi.org/10.3386/w8750

[5] Stein, J.C. (1996) Rational Capital Budgeting in an Irrational World. National Bureau of Economic Research. http://dx.doi.org/10.3386/w5496

[6] La Porta, R., Lopez-de-Silanes, F., Shleifer, A., et al. (1997) Legal Determinants of External Finance. Journal of finance, 1997, 1131-1150. http://dx.doi.org/10.1111/j.1540-6261.1997.tb02727.x

[7] Dobrzynski, J.H. (1993) Relationship Investing. Business Week, 3309, 68-75.

[8] Chen, X., Harford, J. and Li, K. (2007) Monitoring: Which Institutions Matter? Journal of Financial Economics, 86, 279-305. http://dx.doi.org/10.1016/j.jfineco.2006.09.005

[9] Chung, R., Firth, M. and Kim, J.B. (2002) Institutional Monitoring and Opportunistic Earnings Management. Journal of Corporate Finance, 8, 29-48. http://dx.doi.org/10.1016/S0929-1199(01)00039-6

[10] Gillan, S.L. and Starks, L.T. (2000) Corporate Governance Proposals and Shareholder Activism: The Role of Institutional Investors. Journal of financial Economics, 57, 275-305. http://dx.doi.org/10.1016/S0304-405X(00)00058-1

[11] Gillan, S. and Starks, L.T. (2007) The Evolution of Shareholder Activism in the United States. http://papers.ssrn.com/sol3/papers.cfm?abstract id=959670

[12] Brickley, J.A., Lease, R.C. and Smith, C.W. (1988) Ownership Structure and Voting on Antitakeover Amendments. Journal of financial economics, 20, 267-291. http://dx.doi.org/10.1016/0304-405X(88)90047-5

[13] Klein, A. and Zur, E. (2009) Entrepreneurial Shareholder Activism: Hedge Funds and Other Private Investors. The Journal of Finance, 64, 187-229. http://dx.doi.org/10.1111/j.1540-6261.2008.01432.x

[14] Coffee, J.C. (1991) Liquidity versus Control: The Institutional Investor as Corporate Monitor. Columbia Law Review, 91, 1277-1368. http://dx.doi.org/10.2307/1123064

[15] Bushee, B.J. (2001) Do Institutional Investors Prefer Near-Term Earnings over Long-Run Value? Contemporary Accounting Research, 18, 207-246. http://dx.doi.org/10.1506/J4GU-BHWH-8HME-LE0X

[16] Bushee, B.J. (1998) The Influence of Institutional Investors on Myopic R\&D Investment Behavior. Accounting Review, 305-333.

[17] Graves, S.B. and Waddock, S.A. (1990) Institutional Ownership and Control: Implications for Long-Term Corporate Strategy. The Executive, 4, 75-83. http://dx.doi.org/10.5465/AME.1990.4274714

[18] Rhodes-Kropf, M., Robinson, D.T. and Viswanathan, S. (2005) Valuation Waves and Merger Activity: The Empirical Evidence. Journal of Financial Economics, 77, 561-603. http://dx.doi.org/10.1016/j.jfineco.2004.06.015 